\title{
HODGSON v. ROBERT HALL CLOTHES, INC.: CONCEALED SEX .DISCRIMINATION AND THE EQUAL PAY ACT
}

The Equal Pay Act of $1963^{1}$ is a broad, remedial amendment to the Fair Labor Standards Act ${ }^{2}$ intended to eliminate wage discrimination on the basis of sex. ${ }^{3}$ It prohibits employers from remunerating male and female employees who perform substantially equal work at different rates, unless the employer can prove that the wage differential is based on a seniority system, a merit system, a system which measures quantity or quality of output, or the fourth exception, "any other factor other than sex."

Hodgson v. Robert Hall Clothes, Inc. ${ }^{5}$ was an action brought under this Act in 1966 in which the Secretary of Labor asserted that the Robert Hall Store of Greenbank Road, Wilmington, Delaware, a wholly owned subsidiary of Robert Hall Clothes, Inc., had been discriminating against saleswomen since June 13, 1964 , by compensating them at a lower rate than salesmen even though saleswomen and salesmen were performing equal work. ${ }^{6}$ The Greenbank Road store, which primarily sells fitted apparel, ${ }^{7}$ is divided into two departments-one selling men's and boys' clothing; the other, women's and girls' clothing. ${ }^{8}$ The merchandise sold in the men's department is generally more expensive and of better quality than that sold in the women's department. ${ }^{9}$ As a result, the men's department has recorded a larger dollar

129 U.S.C. $\$ 206(d)$ (1970). The Equal Pay Act states in part:

(1) No employer having employees subject to any provisions of this section shall discriminate, within any establishment in which such employees are employed, between employees on the basis on sex by paying wages to employees in such establishment at a rate less than the rate at which he pays wages to employees of the opposite sex in such establishment for equal work on jobs the performance of which requires equal skill, effort, and responsibility, and which are performed under similar working conditions, except where such payment is made pursuant to (i) a seniority system; (ii) a merit system; (iii) a system which measures earnings by quantity or quality of production; or (iv) a differential based on any other factor other than sex . . . .

229 U.S.C. $\S \S 201-19$ (1970).

${ }^{3}$ Hodgson v. Corning Glass Works, 474 F.2d 226, 228 (2d Cir. 1973), cert. granted, 42 U.S.L.W. 3362 (U.S., Dec. 17, 1973). See generally Annot., 7 A.L.R.F. 707 (1971).

${ }^{4}$ Equal Pay Act, 29 U.S.C. \& 206(d)(1) (1970) (quoted in note 1 supra).

5 473 F.2d 589 (3d Cir.), cert. denied, 414 U.S. 866 (1973). For a brief discussion of this case, see Note, 44 Miss. L.J. 1028 (1973).

6473 F.2d at 592 .

${ }^{7}$ See Hodgson v. Robert Hall Clothes, Inc., 326 F. Supp. 1264, 1268 (D. Del. 1971), revid., 473 F.2d 589 (3d Cir.), cert. denied, 414 U.S. 866 (1973).

${ }^{8} 473$ F.2d at 590 .

${ }^{9}$ Id. 
volume in gross sales, and a greater gross profit for every year of the store's operation. ${ }^{10}$ At all times, only men have been employed to seli in the men's department, and only women in the women's department. ${ }^{11}$ Salesmen have always received both a higher starting wage and higher periodic increases than saleswomen. ${ }^{12}$ The Secretary of Labor contended that this pay differential violated the Equal Pay Act with reference to all female sales employees. The district court reached a mixed result on this issue. It found no violation with regard to full-time employees, but found that pay differentials for part-time employees did violate the Act. On appeal, ${ }^{13}$ Robert Hall successfully maintained the affirmative defense that the wage differential for all employees was permissible, as it was exclusively based on the difference in the profitability of the clothing sold by sexually segregated sales personnel, a "factor other than sex."14

This decision is of significance in three respects. First, it implies that in equal pay actions involving retail clothing establishments which limit the performance of certain jobs to a single sex, a finding of noninterchangeability of job performance is basic to a holding of no liability. Furthermore, an employer's allegation of noninterchangeability will not be subject to close judicial scrutiny. Second, by finding that varying average profits among departments with sexually segregated sales personnel justifies comparable wage differentials, the Third Circuit panel introduced the most expansive judicial reading of the fourth exception to the Equal Pay Act. Third, the court broke with previous precedent and failed to require the employer to correlate pay differentials with individual performance, thereby lessening the employer's burden of showing nondiscrimination. By thus deferring to the private determination of noninterchangeability and failing to mandate equal pay scales for both sexes performing the same work, the panel reached a result which implies that the costs created by business policies catering to perceptions of community sexual mores should be borne by the female labor force, rather than the firm.

${ }^{10} \mathrm{Id}$. at 591. See text accompanying note 54 infra.

11473 F.2d at 591 .

${ }^{12}$ Id. at 592 . See text accompanying note 54 infra.

${ }^{13}$ For a description of the procedural history of the case, see 473 F.2d at 592-93.

14 Id. at 592. In an action under the Equal Pay Act, the Secretary of Labor has the burden of establishing a prima facie case of violation of the Act by demonstrating that male and female employees are remunerated unequally for performing substantially equal work. But once the Secretary has made this showing, the burden of proof switches and the employer must prove that the wage differential is justified by one of the four exceptions in order to escape liability. Hodgson v. Corning Glass Works, 474 F.2d 226, 231 (2d Cir. 1973), cert. granted, 42 U.S.L.W. 3362 (U.S. Dec. 17, 1973); Schultz v. Wheaton Glass Co., 421 F.2d 259, 266 (2d Cir.), cert. denied, 398 U.S. 905 (1970). 


\section{Noninterchangeability as a Prerequisite to EsCAPING LIABILITY}

The district court determined that the performance of male and female sales jobs was noninterchangeable, finding that both customers and salespeople would be embarrassed and sales would be inhibited unless the sales personnel were of the same sex as the customer. ${ }^{15}$ In reaching this conclusion, the court accepted the defendant's assertion that the salesperson is frequently required to be in close bodily contact with the customer and to view customers in various states of undress in connection with try-ons. ${ }^{16}$ This determination of noninterchangeability may be viewed as a threshold issue, for if a job is found to be susceptible to performance by both sexes, and the employer has denied members of one sex the opporunity to work at it, then the court would have no choice but to conclude that sex is a factor in the job segregation. Such discrimination would violate not only the Equal Pay Act, but Title VII of the Civil Rights Act of $1964^{17}$ as well, which is in pari materia with the Equal Pay Act. ${ }^{18}$ Robert Hall, the first equal pay litigation against a retail operation which limits employment to a single sex within certain departments, ${ }^{19}$ indicates that regardless of what else a defendant retailer is prepared to plead and prove, if it is unable to demonstrate that jobs limited to one sex are noninterchangeable, it will be held in violation of the Equal Pay Act. ${ }^{20}$

In light of the significance of this finding of noninterchangeability, it is surprising that this issue was neither contested by the Secretary on appeal ${ }^{21}$ nor closely scrutinized by the district and appellate courts. It is unclear from either court

15326 F. Supp. at 1269. But see Diaz v. Pan American World Airways, Inc., 442 F.2d 385 (5th Cir.), cert. denied, 404 U.S. 950 (1971). The court in Diaz rejected Pan American's assessment of the strength of customer preference and the dire consequences resulting from ignoring this preference, in holding that discrimination against male cabin attendants was not permissible under the bona fide occupational exception to Title VII of the Civil Rights Act of 1964,42 U.S.C. $\S 2000 \mathrm{e}-2$ (1970), which is to be narrowly construed to apply only in cases of necessity, not convenience.

${ }_{16} 326$ F. Supp. at 1269.

1742 U.S.C. \& $2000 \mathrm{e}-2(a)(1)(1970)$.

${ }^{18}$ See Schultz v. Wheaton Glass Co., 421 F.2d 259, 266 (3d Cir.), cert. denied, 398 U.S. 905 (1970). See generally Kanowitz, Sex-Based Discrimination in American Law III: Title VII of the 1964 Civil Rights Act and the Equal Pay Act of 1963, 20 Hastings L.J. 305 (1968).

${ }_{19}$ Most litigation under the Equal Pay Act involves factory labor situations. See, e.g., Schultz v. Wheaton Glass Co., 421 F.2d 259 (3d Cir.), cert. denied, 398 U.S. 905 (1970); Schultz v. Saxonburg Ceramics, Inc., 314 F. Supp. 1139 (W.D. Pa. 1973). Of the retail operations involved in equal pay litigation, there has never been one which has limited work within a single department to members of a single sex, although some have paid unequal wages to men and women working at substantially equal jobs within the same department. See, e.g., Hodgson v. Food Fair Stores, Inc., 329 F. Supp. 102 (M.D. Pa. 1971).

${ }^{20}$ Cf. 29 C.F.R. $\$ 800.114$ (a) (1973).

21 See 473 F.2d at 591 . 
opinion why the sex of a salesperson is a bona fide occupational qualification, to use the terminology of Title VII, justifying the exclusion of women from higher paying jobs as a matter of company policy. There was no finding that women have or have not performed successfully in men's and boys' clothing departments in other companies. Nor was there any evidence that practices less objectionable than a denial of female access to higher paying jobs could not be equally effective in avoiding embarrassing measurements near "private parts" and exposure of customer's bodies.

The deference given to the employer's determination of the tastes and inhibitions of his clientele is especially surprising in light of a recent sex discrimination in employment case in the Fifth Circuit. In Wallingham v. Macon Telegraph Publishing Co., ${ }^{22}$ Judge Minor Wisdom's majority opinion found unacceptable a firm's assertion that a male's hair length is sufficient to deny him employment because it "would be offensive to the company [sic] advertisers and customers and would injure the company's business and good will in the community." ${ }^{23}$ The decision was based on the Civil Rights Act of 1964 and its provision which prevents sex discrimination with respect to "compensation, terms, conditions or privileges of employment, because of such individual's ... sex."24 Judge Wisdom recognized the bona fide occupational exception to the requirements of the Civil Rights Act, but held that customer taste could not create such an exception. ${ }^{25}$

In Robert Hall, the employer's assessment of the sexual inhibitions of his clientele should have been given an equally close scrutiny, especially if the congressional purpose of the Equal Pay Act was to eliminate those "subjective assumptions and traditional stereotyped misconceptions regarding the value of woman's work." ${ }^{26}$ Without further findings of fact in Robert Hall, the judicial imprimatur on sexual segregation of opportunity created by Robert Hall is inappropriate. As the discussion in section III infra indicates, this threshold issue is also the central economic issue, for with a privately enforced noninterchange-

${ }^{22} 482$ F.2d 535 (5th Cir.), petition for rehearing en banc granted, 482 F.2d 542 (5th Cir. 1973).

${ }^{23} \mathrm{Id}$. at 537 .

2442 U.S.C. $\& 2000 \mathrm{e}-2$ (a)(1) (1970).

25482 F.2d at 538. See Diaz v. Pan American World Airways, Inc., 442 F.2d 385 (5th Cir.), cert. denied, 404 U.S. 950 (1971) (holding described in note 15 supra). Accord, 29 C.F.R. \& 1604.2(a)(1)(iii) (1973).

${ }^{26}$ Shultz v. First Victoria Nat'l Bk., 420 F.2d 648, 656 (5th Cir. 1969). See 109 CoNG. REc. 9212 (1963) (remarks of Representative Donahue); Murphy, Sex Discrimination in Employment-Can We Legislate a Solution?, 17 N.Y.L.F. 437, 444 (1971):

Perhaps the most popular myth concerning women workers ... involves sex-typing, where women are thought incapable of performing certain jobs. The evidence is quite clear that women can perform any job except that of sperm donor, and it is only tradition, rather than job content, which has led to the labelling of certain jobs as "for men only." 
ability policy, any judicial test of average gross profits will tend to support sex differentials. However, tracing these wage differentials back to this source is useful in determining who bears the cost of catering to community social mores.

\section{The Fourth Exception: Differing Profits Across Sexually Segregated Departments as a JUSTIFICATION FOR Differential WAGeS}

Having found the sex segregation in Robert Hall legitimate, the circuit court considered whether the pay differentials, alleged by Robert Hall to arise from differing market conditions in each segregated department, were also legitimate. The Secretary of Labor argued that a difference in profits from sexually segregated departments, or "economic benefit," cannot be a "factor other than sex" excusing the payment of unequal wages for substantially equal work. ${ }^{27}$ In substance, the government position was that, although the statutory. language of the fourth exception is broadly framed-"a differential based on any other factor other than sex"-both the structure of the Equal Pay Act and its legislative history indicate that the fourth exception should not be read so broadly as to include differences in economic benefit to the employer. ${ }^{28}$

Congress included three specific exceptions to the requirements of the Equal Pay Act under which unequal wages can be paid to male and female employees without violating the statutory ban on sex discrimination. ${ }^{29}$ Each of these three exceptions bears a direct relationship to individual job performance or individual employee qualifications-the employee's experience, ability, or production level. Relying upon Congressman Griffin's statement before the House of Representatives that the first three itemized exceptions "are really examples" of the types of factors which could be taken into consideration in working out the wage differentials under the fourth category, ${ }^{30}$ the Secretary contended that the fourth exception similarly permits only differences in compensation which reflect differences in individual job performance or qualifications. ${ }^{31}$

Robert Hall bases its wage differential on the difference in gross profits between the men's and women's departments, ${ }^{32}$ a difference primarily attributable to the generally higher price of

27473 F.2d at 593.

${ }^{28}$ Brief for Plaintiff at $20-22, i d$.

2929 U.S.C. \& $206(d)(1)(1970)$.

${ }^{30} 109$ ConG. Rec. 9203 (1963).

31473 F.2d at 593 . The Secretary's test would justify differentials based on "any other factor other than sex which is related to job performance or is typically used in setting wage scales."

${ }^{32}$ Id. at 592. 
the merchandise sold in the men's department. ${ }^{33}$ Since the difference in the gross profits of the two departments is completely unrelated to individual job performance or qualifications, the Secretary argued that a wage differential based thereon could not be justified under the fourth exception. ${ }^{34}$

The court rejected this argument, holding that a gross profit differential is a "factor other than sex" under the fourth exception and a permissible basis for wage differentiation between sexually segregated departments. The opinion is based in part on legislative history which indicated to the court that Congress had no intention of denying the employer the option of unequally compensating employees of different sex who perform equal work, provided that the employer's compensation policy is based on a reason other than sex. ${ }^{35}$ The court noted that during the legislative debate, Representative Goodell had asserted that many factors can be considered by employers in determining wages so long as pay differentials are based on these factors and not on the sex of the employees. ${ }^{36}$ Other speeches made during the House debate also indicate that Congress intended that the fourth exception include every reason for a wage differential other than sex. ${ }^{37}$ Although the legislative history does not specifically identify difference in economic benefit to the employer as a "factor other than sex" which could justify a wage differential, the court determined that Congress intended that the fourth exception be read broadly enough to include this justification.

Moreover, the court looked to those regulations and guidelines issued by the Department of Labor which recognize that "factors of value" can constitute a valid basis for unequal payment for apparently equal work, even though this results in inequality between the sexes. ${ }^{38}$ The Wage Hour Administrator's Interpretive Bulletin ${ }^{39}$ and the Field Office Handbook ${ }^{40}$ validate the payment of different rates of commission for merchandise sold in different departments within an establishment, when the merchandise sold in the two departments differs in price, quality, markup, volume, turnover, or ease of selling. However,

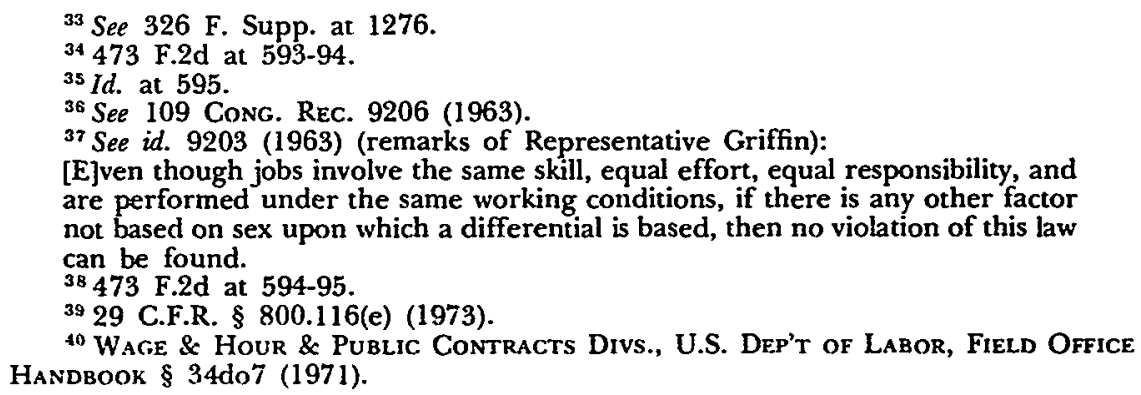


payment by commission is different from the base salary case presented in Robert Hall. Commissions, by definition, are closely related to individual effort, that factor which the Secretary argued was unrecognized in Robert Hall's salary system. The Department of Labor regulations also suggest that employment on a night shift, ${ }^{41}$ assignment to a temporary job, ${ }^{42}$ participation in a bona fide training program, ${ }^{43}$ and employment in a parttime capacity ${ }^{44}$ can all justify a wage differential under the fourth exception. Although the court found the difference in the "economic benefit" conveyed to the employer to be the unifying factor rendering these wage differentials permissible, in each of these examples any wage differential primarily reflects a difference in individual performance.

Thus, Robert Hall stands for the proposition that "economic benefit" can justify a wage differential between sexes. Judge Hunter's opinion for the court is the first explicit judicial statement of this principle. Unfortunately it appears to be based on a confusion in economic analysis. The court accepted as a measure of economic benefit gross profit data, alleged to vary due to the price structures of the segregated departments. However, the regulations cited by the court in support of its position have nothing to do with this price and demand phenomenon, but rather relate most directly to individual worker performance.

\section{The Profits Test: Reducing the Employer's} BURdEN OF SHOWING Nondiscrimination

Cases prior to Robert Hall indicated that, in addition to showing that the factor upon which a wage differential was based was of value to an employer, ${ }^{45}$ the employer had to make two other showings. First, if men and women were treated as separate classes for the purpose of this differential (for example, if all male workers were paid more than all female workers because of extra or different activities said to be performed by the males), the employer had to prove that this separation was based upon some legitimate classification other than sex. ${ }^{46}$ Second, the employer was required to demonstrate that the differential in wages paid to individual employees was reasonably related to the differences in their individual performances. ${ }^{47}$

The figures necessary to make either of the above showings

$\$ 129$ C.F.R. § 800.145 (1973).

42 Id. $\$ 800.147$.

${ }^{43}$ Id. $\$ 800.148$.

14 Id. $\$ 800.150$.

${ }^{45}$ See Schultz v. Wheaton Glass Co., 421 F.2d 259, 266 (3d Cir.), cert. denied, 398 U.S. 905 (1970); Schultz v. Saxonburg Ceramics, 314 F. Supp. 1139, 1146 (W.D. Pa. 1970).

${ }^{46}$ See 421 F.2d at $267 ; 314$ F. Supp. at 1146.

${ }^{47}$ See 421 F.2d at 266-67. 
usually cannot be derived from regular business and bookkeeping records since these records generally focus on figures such as departmental sales, profits, individual hours worked and wages paid, and do not indicate variations in, or the utility of, individual employee performance. ${ }^{48}$ To prove the nondiscriminatory nature of a sexual classification, the employer had to introduce statistics demonstrating that virtually 100 percent of the male and zero percent of the female employees performed the more productive activity. ${ }^{49}$ In most employment situations, the preparation of such a statistical presentation would require interviewing each employee individually and determining whether the employee was willing and able to perform the activity and whether, in fact, the employee actually did so. ${ }^{50}$ Proof of a reasonable relationship between individual job performance and wage differentials required assigning an economic value to the work performed by each male and female employee, and showing that the percentage difference in these values was closely related to the percentage difference in the male and female wage rates. ${ }^{51}$ Consequently, the cases decided prior to Robert Hall indicate that in order to meet its burden of proof, an employer must rely on proof derived from sources other than the regular business and accounting records of the enterprise.

The Secretary of Labor argued that Robert Hall failed to carry its burden of proving the economic benefits upon which the wage differential was allegedly based. ${ }^{52}$ The defendant relied exclusively on group averages obtained from the regular business and accounting records of the enterprise. ${ }^{53}$ It introduced accounting records demonstrating that during the period 1963-1969, the men's department generated gross profits per sales hour seventy-two percent to 134 percent greater than the women's department, and that during the same period the wages paid males exceeded those paid females by twenty-five percent to fifty percent. ${ }^{54}$

The appellate court determined that through the introduction of these records, Robert Hall had effectively shown that the wage differential was based on a factor of value to the employer: greater gross profits per hour. The district court's finding of noninterchangeability of job performance indicated to the court

48 This is the case because figures focusing on the difference in, or the utility of, individual performance are of little value to enterprises which remunerate employees on the basis of an hourly wage or salary, and the vast majority of commercial enterprises in this country employ one of these two systems. Cf. J. Dohr, E. Phillips, G. Thompson \&

W. WARRen, Accounting and the LAW 643-59 (3d ed. 1964).

${ }^{49}$ See 421 F.2d at $267 ; 314$ F. Supp. at 1146.

${ }^{50}$ See 421 F.2d at $259 ; 314$ F. Supp. at 1139.

${ }^{51}$ See 421 F.2d at 266-67.

52473 F.2d at 596-97.

s3 Id. at 591 nn.1, 2.

${ }^{54}$ Id. 
that the defendant had carried its burden of demonstrating that a legitimate business justification for the job separation exists, sufficient to dispel the notion that the separation was based on sex. This showing did not demonstrate that a reasonable relationship exists between wage differentials and differences in individual job performance. The court, however, held that since Robert Hall had shown that it did not base its wage differential on sex, it was not required to correlate the differential with differences in individual performance. ${ }^{55}$ Thus, the employer's burden of proof in this type of equal pay case is considerably reduced.

This reduction in the employer's burden of showing nondiscrimination by the use of a gross profits test is inappropriate for two reasons. First, an employer may be able to show differentials in gross profits per sales hour among sexually segregated departments and still be discriminating on the basis of sex. Second, the use of this test masks the central issue of who should bear the cost of private employment practices designed to accede to customer tastes.

The gross profits measure used by Robert Hall is the difference between the total revenue from retail sales and the cost of merchandise sold. The cost of merchandise and thus the gross profits measure includes among other things sales labor costs. Hence, the gross profits per sales hour differential between the two departments could be attributable to factors other than the differences in unit prices between the departments, which Robert Hall uses as its justification for paying unequal wages.

One such factor is the nature of the firm's demand for its labor force. The industrywide noninterchangeability policy forces all women to work in the women's and girls' department and prevents them from taking advantage of any opportunities in the men's and boys' department. This restriction on female job mobility artificially increases the supply of female labor, reduces their productivity at the margin, and lowers their wage. Depending on the nature of the firm's responsiveness to this drop in wage (its wage elasticity of input demand), the amount spent on female labor could decline and Robert Hall and other retailers of women's apparel would tend to lower their prices under normal competitive pressures resulting from the cost reduction. Thus the artificially low women's wages induced by the industrywide noninterchangeability policy would cause the gross profit measure to decline in the women's and girls' department rather than reflect relatively lower gross profits in that department.

However, in the men's and boys' department economic

${ }^{55}$ Id. at 597. 
forces could be working to increase, rather than decrease gross profits, and therefore widen the differential between departments relied upon by Robert Hall to show that the wage differential is unrelated to sex. The restriction on the supply of female labor could artificially tend to raise the wages of the salesmen, because the supply of labor to their department is less than it would be in the absence of the noninterchangeability restriction. If the response of this department's input demand (and that of other similar departments of other retailers) to the rise in wages is to incur higher men's labor costs resulting in higher retail prices, then the gross profits of the department would increase absolutely and relatively to the women's department.

Therefore, it is possible that the Robert Hall gross profit differential is partially due to wage differences traceable to the industrywide noninterchangeability policy. In addition, from a broader societal perspective it is also possible that the differential is due to lower women's wages generally-traceable to past sex discrimination in employment. Thus, the gross profit differential would not be independent of the sex discrimination practiced by Robert Hall and wage discrimination based on this measure would be wage discrimination on the basis of sex and on its face not within the fourth exception's "any other factor other than sex." Since this issue was never discussed in any of the Robert Hall opinions or briefs, it is unknown whether this analysis is actually applicable to the case, but that is not critical here. The important point is that such analysis might be applicable, and therefore the courts' use of the gross profits test is incorrect because the difference in gross profits may be partially a result of sex discrimination and therefore would be an impermissible factor to consider in setting wage rates. The courts should use such a test only after the employer has clearly proven that it does not reflect hidden sex discrimination.

\section{Conclusion}

The appellate court's opinion observed that adoption of the Secretary's position could force Robert Hall "toward a system based totally upon commissions,"56 thereby endangering the prevailing system of compensation by salary. The Secretary, by contrast, characterized the Third Circuit decision as one which will threaten effective enforcement of the Equal Pay Act in the entire retail sales industry. ${ }^{57}$ It is not apparent that either of

57 Petitioner's Brief for Certiorari at 11, Brennan v. Robert Hall Clothes, Inc., 414 U.S. 866, denying cert. to 473 F.2d 589 (3d Cir. 1973).

A similar view is held by Congresswoman Elizabeth Holtzman who introduced a bill in the House of Representatives, H.R. 12061, 93d Cong., Ist Sess. (1973), soon after the Robert Hall decision to amend the Equal Pay Act by depleting the "other factors" clause completely. 119 Cong. Rzc. H 11909 (daily ed., Dec. 20, 1973). 
these results will follow inevitably from the alternatives faced by the court. However, this Comment has attempted to describe an unfortunate failure of the court to find substantial support either in law of in fact for what may be a sound legal principle-that differing economic benefits to an employer may constitute a valid basis for differentiating between the rates of pay of sexually segregated personnel. Two conditions should be met before this principle is applied, and these conditions were not satisfied in the case at hand. First, there should be clear proof of the need for segregation of the employees by sex. Second, the employer should be required to prove that any wage differential is clearly related to a difference in economic benefit to the employer, a difference not attributable to any hidden sex discrimination. Failure to meet these two conditions can result in a hidden discrimination against the members of one sex, discrimination which the Equal Pay Act of 1963, in conjunction with the Civil Rights Act of 1964, was intended to prevent. 